\title{
SBORNÍK
}

ČESKOSLOVENSKÉ GEOGRAFICKÉ SPOLEČNOSTI

ROČNÍL 1988 C Č́́SLO 2 SVAZEK 93

JOSEF BRINKE

\section{THE CONTRIBUTION OF CZECH SCIENTISTS TO THE NATURAL SCIENTIFIC KNOWLEDGE OF AUSTRALIA}

Presented on the Occasion of the 26th International Geographical Congress in Sydney

The Czechs, a small nation living for centuries in the heart of Europe, have always been interested in learning to know foreign countries. Their initial interest as travellers altered in the course of time into scientific interest. In this sphere their contribution has been sometimes greater than of larger or maritime nations. Naturally, the interest in Australia had been rather smaller than in other continents nearer to Europe and discovered by Europeans earlier. Consequently, the scientiric share of Czech natural scientists as regards Australia is smaller than their contribution to the knowledge of Africa, America or Asia where their work has several times met with international appreciation. Let us mention at least the traveller and physician Emil Holub (1847-1902) who contributed much to the knowledge of South Africa; the American anthropologist of Czech descent - Aleš Hrdlička (1849-1943) who was interested in the problem of the origin of aboriginals in America and studied also the tribes living in Africa, Asia and also in Australia; or the Orientalist Alois Musil (1868-1944), an outstanding connoisseur of West Arabia whose work published mostly in foreign languages, has been acknowledged up to the present time.

In the course of time when Emil Holub carried out his explorations in Africa - at the time of its colonization by the Europeans - no Czech scientist visited Australia to pursuit natural historical studies. Few Czechs, however, of different professions came to Australia at that time and some of them contributed later to a general knowledge of Australia after their return home. The best known was gold-digger Čeněk Paclt (1813-1887). Another of them, Josef Polák (1844-1899), buried in Perth, took part in an expedition led by John Forrest in 1882 to the river Gascoyne in West Australia. Another Czech, Alois Topič (1852-1927) was working long years in Australia as gardener, and later as a hunter of platypus. He was one of the first Europeans who systematically studied the life of Australian duckbills. The public knowledge of Australia in our country was much enriched by popular scientific 
books and lectures by the Czech traveller Josef Kořenský (1847-1938) who carried out his explorations in Australia at the end of the last century.

The scientific interest in Australia had its roots at the Charles University, Prague. The first lectures dealing with the geography of Australia, were delivered by Professor Jan K. Palacky (1830-1908) at the philosophical faculty of the Prague University in the second half of the last century. He was the first to habilitate for an associate professor (docent) in geography in Prague. In the winter term of 1856-57 he gave one lecture every week on "Africa and Australia, a Comparison of Geographical Data" (bibliog. 20, p. 86). In 1885 he became associate professor, in 1891 professor of geography. $\mathrm{He}$ is the author of the first geography of Australia published in Czech. Its first part, the „General Scientific Comparative Geography“ is called „The Illiterate World: Africa, Australia" (bibliog. 28). He wrote then another separate volume on Australia called "Australia“ (29). During the time he was professor at the Czech University, i. e. till 1902, thirteen theses on geography were submitted including one thesis by František Kahlik, treating of Australia and called "The Discovery of the Australian Continent" [submitted in 1884/85). F. Kahlík (1854-1908) graduated from the Prague University, became teacher at a gymnasium and in his free time went on with his studies of Australia. He published several articles, the most extensive of which, called "Australia in the Light of Exploration" appeared as a separate volume $[22\}$.

The first natural scientists to carry out scientific explorations in Australia were the geographer Jiří V. Daneš and the botanist Karel Domin. They both were associate professors at the Charles University, Prague. Jiř́ V. Daneš (1880-1928) graduated in geography, geology and history. After habilitating for doctor of natural sciences in 1902 he pursued his further studies together with the well-known Serbian Professor J. Cvijić whom he joined in an expedition through the Central Balkan where he carried out some geomorphological studies. After a short stay at the Berlin University, he returned to Jugoslavia to continue his studies of the karst in Herzegovina. He presented his results in his thesis in 1906 and was appointed associate professor in general geography. In the same year he took part in the 10th International Geological Congress in Mexico. It was his second trip to the American continent. (His first journey took place in 1904 when he was the only Czech participant at the 8th International Geographical Congress in Washington]. He made several excursions through the North and Central America carrying out geomorphological studies, especially of the karst areas (also on Jamaica). His experiences, gained previously in field investigations, he successfully used in his 15-months journey to Jawa and Australia, which he undertook in July 1909 together with Karel Domin (1882-1953), an associate professor in systematic botany at the Charles University.

After the first part of their journey including explorations on Jawa - Daneš was especially interested in the study of karst phenomena - the two scientists reached the Australian port Townsville in December 1909. After a short stay they arrived at Brisbane, the capital of Queensland. They contacted the authorities, scientific institutions and societies, and then started for Cairns. From here they made expeditions to the Bellenden-Ker Mountains (1579 $\mathrm{m}$ ), to the rivers Russell and Baron, 
to inland areas, to the karst area at Chillagoe, and to the lake Eachan. On their expeditions they met aboriginal Australian tribes living still freely and unrestraint in the bush, took part in their corroborree, and obtained from them many presents of etnographic value. From Cairns they took a ship to Townsville, from where they again made expeditions to inland areas - to Charters Towers, Hugheden, Pentland, Cloncurry, Longreach and back via Rockhampton to Brisbane. Domin left then for Melbourne and returned to his country. Daneš continued his journey alone to carry out his geomorphological studies during the dry period in Western and Northern Queensland. He travelled from Brisbane via Rockhampton to Barcaldine and Aramac, then continued on horseback towards the north to the area of salt lakes (Lake Mueller, Barcoorah, Dunn, Galilee, Buchanan), then to Pentland, Cloncurry to the upper course of the rivers Burdekin and Flinders to Camooweal until he reached the karst area of Barkly Tableland, where he made his investigations. He went on to Gulf of Carpentaria to Gregory Downs and Burketown. On his return way he visited lower Flinders, Normanton, Croydon and Charleston, and then returned back to Cairns. He once more visited the waterfalls in the valley of the Barron and came back to Brisbane, where he gave lectures on his explorations. From Brisbane he went to Sydney, visited the Jenolan Caves, and via Melbourne and Adelaide went to Perth. He carried out some investigations in the karst area near Yallingup and in the gold-bearing area of Coolgardie and Kalgoorlie. In August 1910 he returned to his country.

After his return home Daneš was appointed full professor at the Charles University (1919). To Australia he returned once more to enter in Sydney the office of the General Consul of the newly formed Czechoslovak Republic (1920-1922). At first he was fully occupied with official business matters and could undertake only short excursions to the environment of Sydney. Much attention he paid to lecturing on Czechoslovakia being eager to propagate his land among Australian people as much as he could. A longer expedition he made with his wife in 1921 to New Guinea, the Bismarck Islands and to Northern Queensland. At the end of the year he visited Tasmania and in the following year travelled to the river Murrumbidgee, to the town Yass and to the area of Canberra as far as the Queensland frontier. His duties did not allow him to undertake longer expeditions, therefore, in 1922, after two years of office, he hesitated whether to take part in another long-lasting expedition through Central Australia or whether to return via Oceania to his country. Having not enough time or means to undertake both of these, he decided to return home via Oceania where he wanted to study the origin and the causes of extinction of aboriginals. He visited New Zealand, Fiji, Tonga, Western Samoa Isl., Hawaiian Islands, Japan and China. From China he took a ship to Vancouver and across Canada returned to Europe. In 1928 he made his last overseas trip to the USA, where he was killed in a car accident in Los Angeles a year afterwards.

He left an extensive yet unfinished work, the greatest part of which deals with Australia. In his work he concentrated on physical geography, especially geomorphology being before all interested in the study of karst forms. In this sphere he achieved international fame. In Australia he carried out his studies predominantly in out-of-the-way karst areas or areas not yet investigated at all. This was his great contribution to 
the natural historical science. His works treating of the Australian (and non-Australian) tropical karst have been quoted up to the present time. He was also well known as anthropogeographer, and one of the most interesting works is his book dealing with aboriginals in Australia and Oceania (15). Although it has been surpassed in some respect in the course of time, it contains a lot of valuable thought and observations due to his autopsy. ${ }^{*}$ ]

K. Domin has not reached such an international apppreciation as Daneš, yet his phytogeographical works concerning Australia have highly been appreciated in scientific circles. The most important of his works in this sphere is his work published in German in 1926, in which he describes a large variety of species, varieties and forms he collected in Australia together with the description of their occurrence (19).

In 1934 another Czech, the zoologist Jiři Baum (1900-1940) visited Australia in the company of his wife. He studied zoology at the Charles University from where he took his degree as doctor of natural sciences in 1928. His special branch was arachnology - the science of spiders; he was also interested in birds and insects. Both Daneš and Baum were financially independent and that enabled him to travel. To the contrary to Daneš, however, he could use a modern vehicle, a motorcar. He crossed Africa by this means, studying and collecting the local fauna. His journey was a good preparation for his tour of the world, including Australia. At the beginning of 1935 accompanied by his wife he took a ship to Freemantle. He had a motor caravan of the Czechoslovak make Tatra whose boxvan body could be adapted to a laboratory or a dark room. At first he travelled through the southwest of Australia, and then crossed Australia from Perth via Kalgoorlie, Madura, Eucla, Penong, Port Augusta and Adelaide to Melbourne. From there he continued via Canberra to Sydney and along the eastern coast up to Brisbane. There he left his car and went by train to Cairns, from where he made an excursion to the Great Barrier Reef. He was a pioneer in using a car of Czechoslovak make for such a long journey across the Australian continent. During his trip he collected zoological material and photographed. From Australia he went to Japan on board a ship, continued to California and across the Panama Canal he returned on ship board to Europe where he finished his tour of the world in 1936. Then he went once again to Africa and returned home close before the occupation of Czechoslovakia by the Nazis. He joined an antifascist resistance movement, was soon arrested and died in 1940 in a concentration camp in Warsaw, Poland.

Baum's contribution to the natural historical knowledge of Australia is rather modest in comparison with that of Daneš and Domin. His Australian trips resulted in a few professional papers on Australian spiders and their biology. Nevertheless he collected large amounts of valuable zoological material for the National Museum in Prague. Unfortunately he coud not sort out the collected material himself, and

*) The limited extent of this paper does not allow any more detailed evaluation of his work and results of his scientific studies in Australia. Therefore we recommend to consult the papers by his friends and collaborators published in the Sborník ČSZ (Život a práce prof. J. V. Daneše. - SČSZ, 34, p. 129-225, Praha 1928). It also appeared as a separate paper (also in English). 


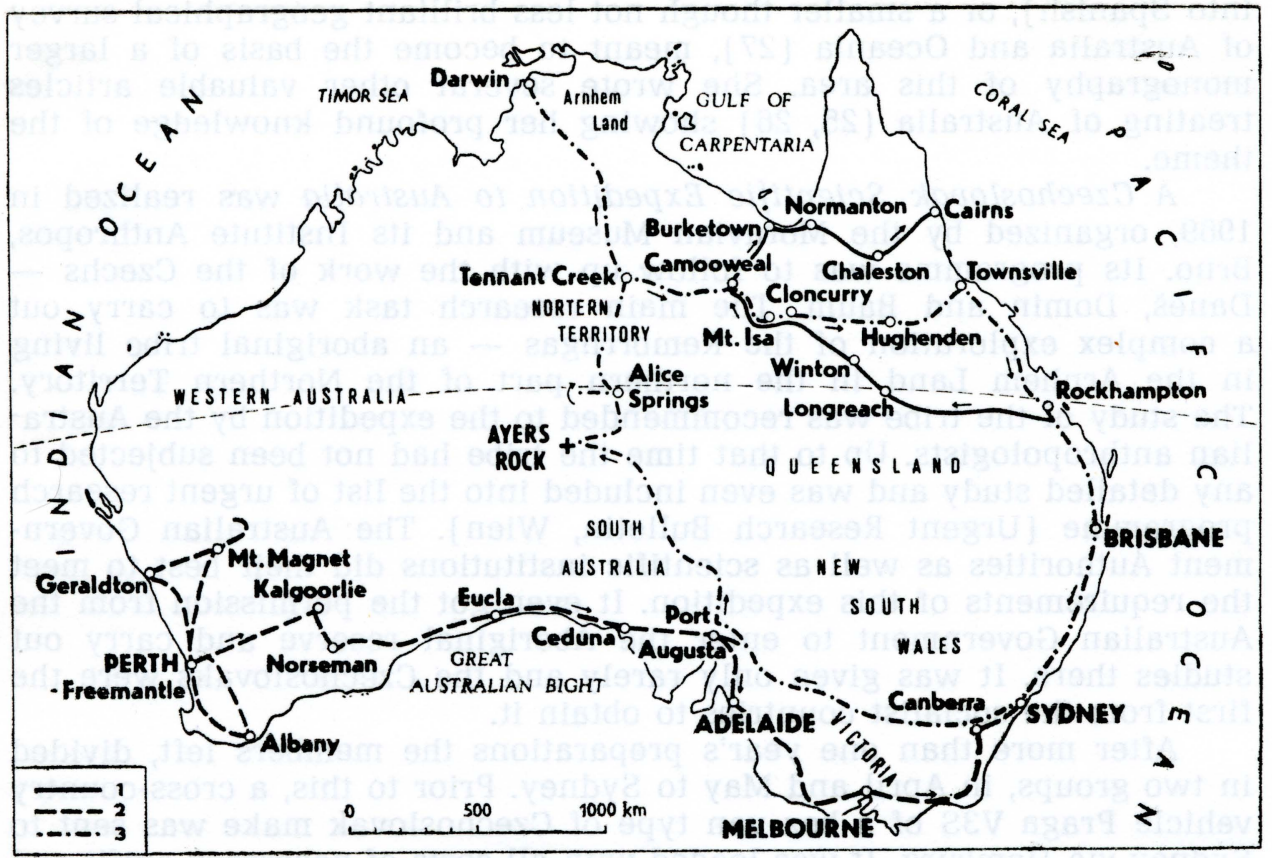

1. Routes of Czech natural scientists in Australia. 1 - the route of journey of J. Daneš through Queensland in 1910, 2 - the route of a car ride of J. Baum through Australia in 1935, 3 - the route of the Czechoslovak expedition from Sydney to Darwin and back to Sydney in 1969.

thus his scientific work has remained unfinished. More known are his popular scientific and travel books. One of them called „A Tour of the World by Car and Ship" (Prague, 1937) includes his description of his voyage to Australia.

During the World War II, another outstanding Czech geographer Julie Moschelesová (1892-1956) lived in Australia. She studied in Norway, took her degree of Doctor of Philosophy in Prague in 1917, where she started her scientific career and thanks to her scientific erudition 'wrote several original books. After 16 years of scientific work she became private docent in 1934. Five years later she had to leave her country before the Nazis and found her position at a School of Economics in Melbourne. Her preparations for the exploration of Oceania were interrupted by the war with Japan. She was appointed a geographical expert in the army of the Dutch East India founded at that time in Northern Australia. In 1946 she returned to Prague where she worked at the Charles University until her death in 1956 (from 1954 as associate professor of geography). Her work was highly appreciated on the occasion of her 60th birthday anniversary by the Academician R. Kettner (23), and the geographer Professor J. Korčák (SČSZ, 61, p. 152-153, Praha 1956). In his opinion J. Moschelesová, who worked in the sphere of physical, economic and regional geography, showed a special erudition in her works for the geographical synthesis. As an example we may quote her large monography on the British Isles (translated also 
into Spanish), or a smaller though not less brilliant geographical survey of Australia and Oceania (27), meant to become the basis of a larger monography of this area. She wrote several other valuable articles treating of Australia $(25,26)$ showing her profound knowledge of the theme.

A Czechoslovak Scientific Expedition to Australia was realized in 1969 , organized by the Moravian Museum and its Institute Anthropos, Brno. Its programme was to follow up with the work of the Czechs Daneš, Domin and Baum. The main research task was to carry out a complex exploration of the Rembrrngas - an aboriginal tribe living in the Arnhem Land in the northern part of the Northern Territory. The study of the tribe was recommended to the expedition by the Australian anthropologists. Up to that time the tribe had not been subjected to any detailed study and was even included into the list of urgent research programme (Urgent Research Bulletin, Wien). The Australian Government Authorities as well as scientific institutions did their best to meet the requirements of this expedition. It even got the permission from the Australian Government to enter the Aboriginal reserve and carry out studies there. It was given only rarely and the Czechoslovaks were the first from the socialist countries to obtain it.

After more than one year's preparations the members left, divided in two groups, in April and May to Sydney. Prior to this, a cross-country vehicle Praga V3S of a box van type of Czechoslovak make was sent to Sydney via Hamburg. It was loaded with all sorts of necessary outfit and accessories and supplies. Moreover in Sydney the expedition was provided with two cars of the Land Rover type lent by the Australian Government. In the middle of May the three vehicles started their way across the continent via Port Augusta, Ayers Rock and Alice Springs to Darwin. The trip from Sydney to Darwin lasted one month. Much of this time the zoologist $\mathrm{Z}$. Veselovský spent carrying out his zoological studies and collecting samples.

At the beginning of July the expedition left Darwin and moved towards the south to a government Aboriginal Settlement Bamyili located some $70 \mathrm{~km}$ south-east of Katherine. There the expedition divided into two groups, each trying to fulfill all planned tasks within three months. The field work in this area can be carried out only in the dry period before the rains start at the beginning of October. The main task of the first group was to study the material culture of aboriginals with a special interest in the Rembrrnga tribe. It was led by the physical anthropologist J. Jelínek, head of the Anthropos Institute and director of the Moravian Museum. Other members of this group were the etnograph S. Novotný, the camera operator J. Vrožina, the driver and mechanic J. Daněk, and the government observer E. Brandl. The second group interested in the anthropological, demographic and settlement-geographical conditions of the Rembrrnga tribe was composed of the expedition leader and geographer J. Brinke, and the physical anthropologist M. Prokopec.

The first group left Bamyili heading towards the east to Mainoru, the last cattle station located on the southern border of the A. L. Reserve. Then the scientists started a difficult way across the Arnhem Land to the northern coast to the government settlement Maningrida. The drive through the bush was very uneasy, leading through tracks of land scar- 
cely visited by Man before. The place for their first camp they found in the central part of the area inhabited by the Rembrrnga tribe near Bulman Waterhole yielding rich discoveries of stone implements. Another area under study was Bulman Gorge where several caves with perfect rock-wall paintings were mapped. In the middle of $\mathrm{Au}^{-}$ gust the group moved to the river Cadell, a rocky country with numerous caves in which rich discoveries of stone implements including the original stone tool-making workshops were made. Here the expedition met the family of Mandarg, an aboriginal, who, with his sons still knows how to cut stone to make stone implements as well as how to make rock-wall paintings or paintings on bark. The scientists naturally took advantage of this unique occasion for a most detailed film and

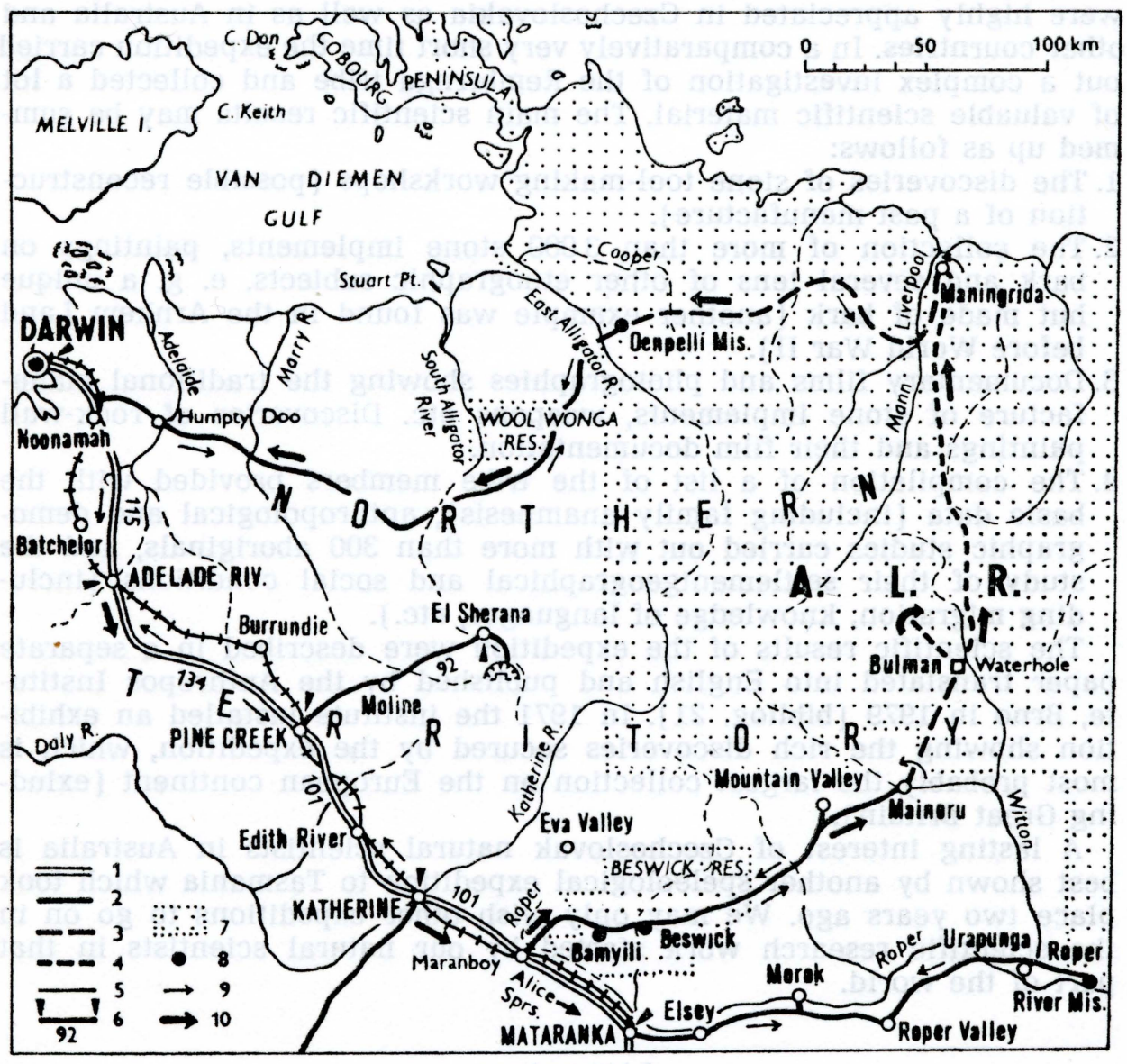

2. The route of the Czechoslovak expedition in the Arnhem Land. 1 - Stuart Highway, 2 - major roads (all weather), 3 - tracks (for 4-whel drive vehicles only), 4 - track in bush, 5 - railways, 6 - distances in $\mathrm{km}, 7$ - Aboriginal reserves, 8 - governments Aboriginal settlements, cattle stations and missions, 9 - the route of the second working group, 10 - the route of the first working group. A. L. R. - Arnhem Land Aboriginal Reserve. - Drawn by H. Landová. 
Tiii:

photograph documentation. On their return way via Maningrida and Oenpelli to Darwin they again investigated rock-wall paintings.

The second group was predominantly interested in anthropological and demographic investigations. They planned to collect information on the corporeal and biological characteristics of the Rembrrngas, to gain photographic documentation and to study their demographic, settlement-geographical and social conditions. It was necessary to visit the members of the tribe living scattered in many parts of the Arnhem Land in government settlements, government or privateowned cattlestations or missions. Nevertheless, the scientists succeeded in carrying out anthopological and demographic studies with more than 300 aboriginals, and in compiling a list of the tribe members.

At the beginning of October both groups met in Darwin from where they returned to Sydney, this time via Tennant Creek, Mt. Isa, Townsville and Brisbane. The expedition was very successful and its results were highly appreciated in Czechoslovakia as well as in Australia and other courntries. In a comparatively very short time the expedition carried out a complex investigation of the Rembrrnga tribe and collected a lot of valuable scientific material. The main scientific results may be summed up as follows:

1. The discoveries of stone tool-making workshops (possible reconstruction of a past manufacture).

2. The collection of more than 3000 stone implements, paintings on bark and several tens of other etnographic subjects, e. g. a unique hut made of bark (another example was found in the Arnhem Land before World War II).

3. Documentary films and photographies showing the traditional manufacture of stone implements, weapons etc. Discoveries of rock-wall paintings and their film documentation.

4. The compilation of a list of the tribe members provided with the basic data (including family anamnesis), anthropological and demographic studies carried out with more than 300 aboriginals, and the study of their settlementgeographical and social conditions (including migration, knowledge of languages, etc.).

The scientific results of the expedition were described in a separate paper translated into English and published by the Anthropos Institute, Brno in 1979 (bibliog. 21). In 1971 the institute installed an exhibition showing the rich discoveries secured by the expedition, which is most probably the largest collection on the European continent (exluding Great Britain).

A lasting interest of Czechoslovak natural scientists in Australia is best shown by another speleological expedition to Tasmania which took place two years ago. We may only wish other expeditions to go on in the scientific research work started by our natural scientists in that part of the world.

\section{Literature:}

1. BRINKE J.: The Expedition of Czech Scientists to Australia. Acta Universitatis Carolinae, Geographica, Praha, Universita Karlova, 1970, No. 2, p. 93-101.

2. BRINKE J.: Beswick Aboriginal Reserve, Arnhem Land, Australia. (An example of contemporary geographical conditions on Australian Aboriginal settlement]. Acta 
Universitatis Carolinae, Geographica, Praha, Universita Karlova, 1974, No. 1, p. $51-75$.

3. BRINKE J.: Settlement Geography of Rembrrnga Tribe of Arnhem Land. Folia Facultatis Scientiarium Naturalium Univ. Purk. Brunensis, Tomus XIV, Geographia 9, opus 13, Brno, 1974, p. 109-121.

4. BRINKE J.: Neke karasteristike akulturacije australijskih domorodaca. (Quelques traits de l'acculturation des aborigines Australiens. Etude de géographie sociale). Glasnik srpskog geografskog društva (Bulletin de la sociéte Serbe de geographie ], 54, Beograd 1974, No. 1, p. 7-19.

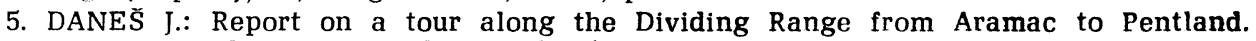
Queensland Geographical Journal, 25, Brisbane 1910, p. 83-103.

6. DANES J.: Some problems of Queensland Hydrography. Queensland Geographical Journal, 25, Brisbane 1910, p. 75-82.

7. DANES J.: Physiography of some limestone areas in Queensland. Proceedings of the Royal Society of Queensland, 23, Brisbane 1910, p. 75-83.

8. DANES J.: On the physiography of Northeastern Australia. Věstník král. České společnosti nauk, tř. mat. př́r., No. 32, Praha 1911, 18 p.

9. DANES J.: Krajinné typy $\mathrm{v}$ severovýchodní Australii. SC̄SZ, 18, Praha 1912, p. 214-221.

10. DANEŠ J.: La capture de la haute Flinders. La Géographie, 26, Paris 1912, p. 263269.

11. DANES J.: La région des Rivières Barron et Russell (Queensland). Annales de Géographie, 21, Paris 1912, p. 346-363.

12. DANEŠ J.: Die tropische Nordostküste Australiens. Die Erde, 1, Weimar 1912/13, p. $100-103 ; 125-129$.

13. DANEŠ J.: Karststudien in Australien. Věstník král. české společností nauk, tř. mat. př́r., No. 6, Praha 1916, 75 p.

14. DANES J.: Limestone physiography in Australia. Recueil de travaux offert a $M$. Jovan Cvijić par ses amis et collaborateurs, Beograd 1924, p. 337-340.

15. DANES J.: Původ a zanikání domorodců v Australii a Oceanii. (Origin and extinction of the aboriginals in Australia and Oceania). Země a lidé sv. 50, Praha, Unie 1924, 137 p.

16. DANEŠ J.: Osamocenost Australie. Studie anthropogeografická. Nár. vĕstník čsl., 18, Praha 1925. p. 162-175. (tamtéž anglicky: The Isolation of Australia. A study in Human Geography, p. 175-190).

17. DANES J.: Tři léta při Tichém oceáně. (Three years in the Pacific). Díl I: Australie. 672 p. Díl II: Oceanie, Japonsko, Č́na, Kanada. 640 p. Nakl. F. Borový, Praha 1926.

18. DANEŠ J. - DOMIN K.: Dvojím rájem. (Through a double paradise. Java and Australia.) Díl 1: Cesta na Jávu a po Jávě. 540 p. Díl II: Cesta po Austrálii a Ceylon. 798 p. Nakl. J. Otto, Praha 1911/12.

19. DOMIN K.: Beiträge zur Flora - und Pflanzengeographie Australiens. Bibliotheca botanica Heft 89 III: 1 T, p. $341-840$, species $1628-1926$, fig. $142-149$, tab. 26-28, Stuttgart 1926.

20. HÄUFLER V.: Dějiny geografie na Universitě Karlově 1348-1967. Geschichte der Geographie an der Karls-Universität. Praha, Universita Karlova 1967, 421 p.

21. JELINEK J. (edit.): Anthropology of the Rembrrnga People. A Contribution of the Czechoslovak Anthropos Expedition to Arnhem Land N. T. Australia. Anthropos Institute - Moravian Museum, Brno 1979, 325 p.

22. KAHLİK F.: Australie ve světle výzkumův. Stat' $z$ dějin zeměpisu. Praha, nakl. J. Otto $1888,112 \mathrm{p}$.

23. KETTNER R.: K šedesátinám Julie Moschelesové. SČSZ, 57, Praha, NČSAV 1952, No. 1 , p. $19-25$.

24. KUNSKÝ J.: Čeští cestovatelé. II. díl. Praha, Orbis 1961, 492 p.

25. MOSCHELESOVĀ J.: Populační ráz australského státu Victoria. (Population character of the Australian state Victoria). Kartografický přehled, 1, Praha 1946, p. 86-91.

26. MOSCHELESOVĀ J.: Australská variace vylidñování venkova. (The Australian variety of the depopulation of the countryside) SČSZ, 57, Praha, NČSAV 1952, p. $101-105$.

27. MOSCHELESOVĀ J.: Australie a Oceanie. Učební texty vysokých škol. Praha, Stấtní pedagogické nakladatelství 1953, 70 p. 
28. PALACKȲ J.: Zeměpis všeobecný, vědecký, srovnávací (Afrika, Australie). Praha, nakl. Bellmann 1857, 587 p.

29. PALACKYY J.: Australie. Zeměpisný obraz. Praha, nakl. M. Knapp 1883, 48 p.

SČSZ - Sborník české (od r. 1921 československé) společnosti zeměpisné Journal of the Czech (since 1921 Czechoslovak) Geographical Society

\author{
Shrnutí
}

\begin{abstract}
PODIL ČESKÝCH VĚDCÕ NA PR̆IRODOVĔDNEM POZNĀNİ AUSTRĀLIE VËNOVĀNO 26. MEZINÁRODNIMUU GEOGRAFICKÉMU KONGRESU V SYDNEY
\end{abstract}

V průběhu minulého století nenavštívil Austrálii žádný česky vědec, aby zde konal př́rodovědné výzkumy. Ovšem již tehdy se tam dostala rada Čechů, z nichž někteří přispěli $\mathrm{k}$ Šíření znalostí o Austrálii ve své vlasti. Jeden $\mathrm{z}$ nich, Josef Polák (1844-1899), se zúčastnil v r. 1882 výzkumné výpravy Johna Forresta k řece Gascoyne. Alois Topič (1852-1927) pracoval v Austrálii řadu let jako zahradník a později jako lovec ptakopysků; byl jedním z prvních Evropanů, kteři se systematicky zabývali jejich životem.

Vědecký zájem o Austrálii vznikl především na Karlově univerzitě v Praze, kde první zemépisné přednášky o tomto kontinentu vedl již v r. 1856/57 Jan Palacký (1830-1908), první habilitovaný docent geografie. Ten je též autorem první česky psané geografie Austrálie $(28,29)$. Historické geografii Austrálie se v té době věnoval František Kahlík (1854-1908).

Prvními př́rodovědci, kteří se do Austrálie vydali za vědeckými výzkumy, byli’ geograf Jiř̆ V. Daneš a botanik Karel Domin, docenti Karlovy univerzity v Praze. Jiří V. Danes (1880-1928) podnikl řadu výzkumných cest po Evropè i po Severní a Střední Americe, kde se věnoval studiím geomorfologickým, zejména krasovým. Zkušenosti využil při své patnáctiměsíční cestě na Jávu a do Austrálie, kterou nastoupil v r. 1909 s Karlem Dominem (1882-1953). Po první etapě cesty, zahrnující výzkumy na Jávě, dosáhli oba vědci v prosinci 1909 Brisbane, kde navázali styk s úrady a vědeckými institucemi. Odtud cestovali do Cairnsu, jenž se stal východiskem pro cesty po severovýchodnim Queenslandu. Konali výzkumy $v$ pohoři Bellenden-Ker, $v$ povodí řek Russell a Barroon, $v$ krasu $u$ Chillagoe a u jezera Eachan. Pak pluli do Townsville, odkud podnikali výpravy do vnitrozemí - do Charters Towers, Hughedenu, Pentlandu, Cloncurry, Longreachu; zpět do Brisbane se vrátili přes Rockhampton. Domin se pak přes Melbourne vrátil do vlasti a Daneš se vydal do západního a severního Queenslandu, aby zde konal geomorfologická studia. Jel z Brisbane přes Rockhampton do Barcaldine a Aramacu, dále pak do oblasti solných jezer (Lake Mueller, Barccorah ad.), potom do Pentlandu, Cloncurry, na horní tok rek Burdekin a Flinders do Camoowealu a dále až do krasového území Barkly Tableland. Navštívil Burketówn ( $\mathrm{v}$ jeho okolí bylo později jedno $z$ údolí nazváno jeho jménem) a vracel se zpět přes dolní Flinders, Normanton, Croydon a Charleston do Cairnsu). Z Cairnsu odjel do Brisbane, kde přednášel o svých výzkumech. Odtud jel do Sydney, dále přes Melbourne a Adelaide do Perthu, odkud navštívil zlatá pole u Kalgoorlie a Coolgardie. V ř́jnu 1910 se vrátil do vlasti.

V r. 1919 byl Daneš jmenován řádným profesorem geografie na Karlově univerzitě. Do Austrálie se vrátil jako generální konzul Ceskoslovenské republiky. Tento úřad $v$ Sydney zastával od srpna 1920 do konce roku 1922; svého pobytu využil k exkurzím, mj. i na Novou Guineu a na Tasmánii. Zpáteční cestu přes Oceánii Danes využil ke studiu původu a vymírání původního obyvatelstva. V r. 1928 zahynul při tragické autonehodě u Los Angeles v USA. Zanechal rozsáhlé, i když nedokončené vědecké dílo, v němž práce věnované Austrálii zaujímají význačné místo. Nejcennější jsou jeho studie o krasu, podnes oceňované a citované. Věnoval se také antropogeografii a mezi jeho pracemi s australskou tematikou vyniká studie o pưvodním obyvatelstvu Austrálie a Oceánie (15).

K. Domin sice nedosáhl takového mezinárodního uznání jako Daneš, př̀esto však jsou jeho fytogeografické práce z Austrálie v odborných kruzích oceñovány (19).

V r. 1934 se do Austrálie vydal zoolog Jiř́ Baum (nar. 1900). Vystudoval zoologii na Karlově univerzitě a specializoval se na arachnologii - vědu o pavoucích. Věnoval se však i studiu ptákủ a hmyzu. Na rozdíl od Daneše již ke svým ces- 
tám používal automobil. Procestoval Afriku a získal zkušenosti pro cestu kolem světa, zahrnující i Austrálii. Baum tam připlul počátkem r. 1935 se svou ženou a s obytným automobilem značky Tatra. Nejdříve procestoval australský jihozápad a projel např́č Austrálií z Perthu přes Kalgoorlie, Maduru, Euclu, Port Augustu a Adelaide do Melbourne, odkud pokračoval přes Canberru do Sydney a dále až do Brisbane. Baum byl první, kdo projel australský kontinent československým automobilem. Během své cesty prováděl zoologické sběry a fotografoval. Z Austrálie plul lodí do Japonska, odkud se vrátil domů přes Panamský prủplav. Za nacistické okupace C̄eskoslovenska byl zatčen a v r. 1940 zemřel v koncentračním táboře ve Varšavě. Baumův podíl na přírodovědném poznání Austrálie je skromnější než Danešův - je to jen několik odborných pojednání o australských pavoucích a jejich biologii. Shromáždil však značné zoologické sběry, jimiž obohatil Národní muzeum v Praze; $k$ jejich zpracování se již sám nedostal.

$\mathrm{Za}$ druhé světové válkv pobývala v Austrálii vynikající česká geografka Julie Moschelesová (1892-1956). Studovala v Norsku. ale doktorátu filozofie dosáhla v r. 1917 v Praze na Karlově univerzitě. Napsala řadu geografických, převážně fyzickogeografickv́ch studií, mezi nimi i několik knižních. z nichž nejcennější byla monografie o Britskúch ostrovech. přeložená i do španělštiny. V r. 1939 musela opustit svou vlast a našla si vysokoškolské zaměstnání v Melbourne, kde působila na Vysoké škole obchodní. Připravovala se na výzkum v Oceánii, který ií však znemožnila válka $s$ Japonskem. Vstoupila pak iako geografický expert do služeb armády Nizozemské Východní Indie, která se tehdy tvořila v severní Austrálii. V r. 1946 se vrátila do vlasti, kde působila až do své smrti na Karlově univerzitě. T. Moschelesová, která se věnovala jak fyzické, tak hospodářské a regionální geografii, prokázala mimořádnou schopnost pro geografickou syntézu. Svědčí o tom mj. rozsahem sice nevelký, ale obsahově bohat̂́ zeměpisnú přehled Austrálje a Oceánie (27), jenž se měl stát základem široce pojaté monografie. Cenné jsou i její další práce s australskou tematikou $(25,26)$.

V r. 1969 se uskutečnila C̄eskoslovenská vĕdecká expedice do Austrálie, organizovaná Moravskv́m muzeem v Brně. Jeiím hlavním vĕdecko-výzkumným úkolem bylo provést komplexní výzkum jednoho z domorodx́ch kmenů - Rembrrnga, žijícího v Arnhemské zemi v severní části Severního teritoria. Australské vládní orgány a vědecké instituce vycházely expedici vstříc a australská vláda jí poskytla i povolení ke vstupu do domorodé rezervace Arnhemská země. Čs. expedice byla první vědeckou výpravou ze socialistických zemí, které to bylo umožněno.

V dubnu a v květnu odieli členové expedice do Sydnev. kam byl též odeslán lodí expediční nákladní terénní automobil Praga V3S ve skřińové úpravě $\mathbf{s}$ výstroií, výzbrojí a zásobami. V Sydney byly převzaty dva terénní osobní vozy Land Rover, zapůjčené australskou vládou. Více než měsíční přesun expedice ze Sydney do Darwinu, vedoucí po trase Sydney - Port Augusta - Ayers Rock - Alice Springs - Darwin. využil zoolog Zdeněk Veselovský $\mathrm{k}$ četnúm zoologickv́m nozorováním a sběrům. Počátkem července vyrazila expedice $z$ Darwinu na iih do vládní domorodé osady Bamyili. Zde se expedice rozdělila na dvě pracovní skupiny. Ǔkolem první vedené antropologem a archeologem Tanem Telínkem. $\mathrm{v}$ níž dále byli etnograf Stanislav Novotny, kameraman Jiřj Vrožina. řjdič a mechanik Tan Daněk a vládní pozorovatel Eric Brandl, byl výzkum materiální kultury domorodců. Úkolem druhé skupiny, tvořené geografem a vedoucím expedice Iosefem Brinkem a antropologem Miroslavem Prokopcem, byl antropologický. demografický a sídelně geografický výzkum kmene Rembrrnga. První skupina odjela do Mainoru, poslední dobytkářské stanice, ležící na jižních hranicích rezervace Arnhemská země. Odtud nastoupila obtížnou cestu málo prozkoumanym terénem napříč Arnhemskou zemí ǎ $k$ severnímu pobřeží $k$ osadě Maningrida, odkud se přes Oenpelli vrátila zpět do Darwinu. Podařilo se í́ objevit radu lokalit s kamennými nástroii. včetně ieiich výroben, lokalit se skalními malbami a u řeky Cadell se setkala s rodinou domorodce Mandarga, který ještě se svými syny ovládal techniku výrobv kamennv́ch nástroiů, malbu na skálu i na kůru. Členové skupiny využili této jedinečné příležitosti $\mathrm{k}$ podrobné filmové a fotografické dokumentaci. Druhá skupina navštívila všechna sídla. $v$ nichž žili př́slušníci studovaného kmene, pořídila jejich seznam a provedla antropologické a demografické šetření u více než 300 domorodců.

Počátkem řijna se obě skupiny spoiily v Darwinu, odkud byl zahájen přesun zpět do Sydney, tentokrát přes Tennant Creek. Mt. Isa, Townsville. Brisbane. Expedice jako celek byla úspěšná a odborníci oceňovali, že se jí podařilo $v$ poměrně krátké době provést komplexní výzkum kmene a shromáždit z.načné a unikátní sbírky (přes 3 tisíce kamenných nástrojû, kolckce maleb na kůře, několik desítek dat- 
ších etnografických předmětů]. Vědecké výsledky expedice byly publikovány ve sborníku, vydaném v angličtině v r. 1979 ústavem Anthropos v Brně (21), kde byla v r. 1971 instalována výstava $z$ bohatých sběrů expedice.

Obr. 1 - Cesty českých přírodovědců Austrálií. 1 - trasa cesty J. Daneše po Queenslandu v r. 1910,2 - cesty J. Bauma autem po Austrálii v r. 1935, 3 - trasa přesunu Čs. expedice ze Sydney do Darwinu a zpět v r. 1969.

Obr. 2 - Trasa Čs. expedice v Arnhemské zemi. 1 - Stuartova silnice, 2 - silnice s prašnym povrchem, 3 - cesty sjízdné jen terénními vozidly, 4 - průjezd 1. skupiny bušem napříč Arnhemskou zemí, 5 - železnice, 6 - vzdálenosti na Stuartově silnici v km, 7 - domorodé rezervace, 8 - vládní domorodé osady a dobytkářské stanice, 9 - směr cesty 2. praçovní skupiny, 10 - smĕr cesty 1. pracovní skupiny. A. L. R. - domorodá rezervace Arnhemská země. Kreslila H. Landová.

(Pracoviště autora: Katedra učitelství a didaktiky geografie UK, Albertov 6, 12843 Praha 2.J

Došlo do redakce 5. 1. 1988. 
1. Brinke: The Contribution of Czech Ścientists to the Natural Ścientific Knowledge of Australia.

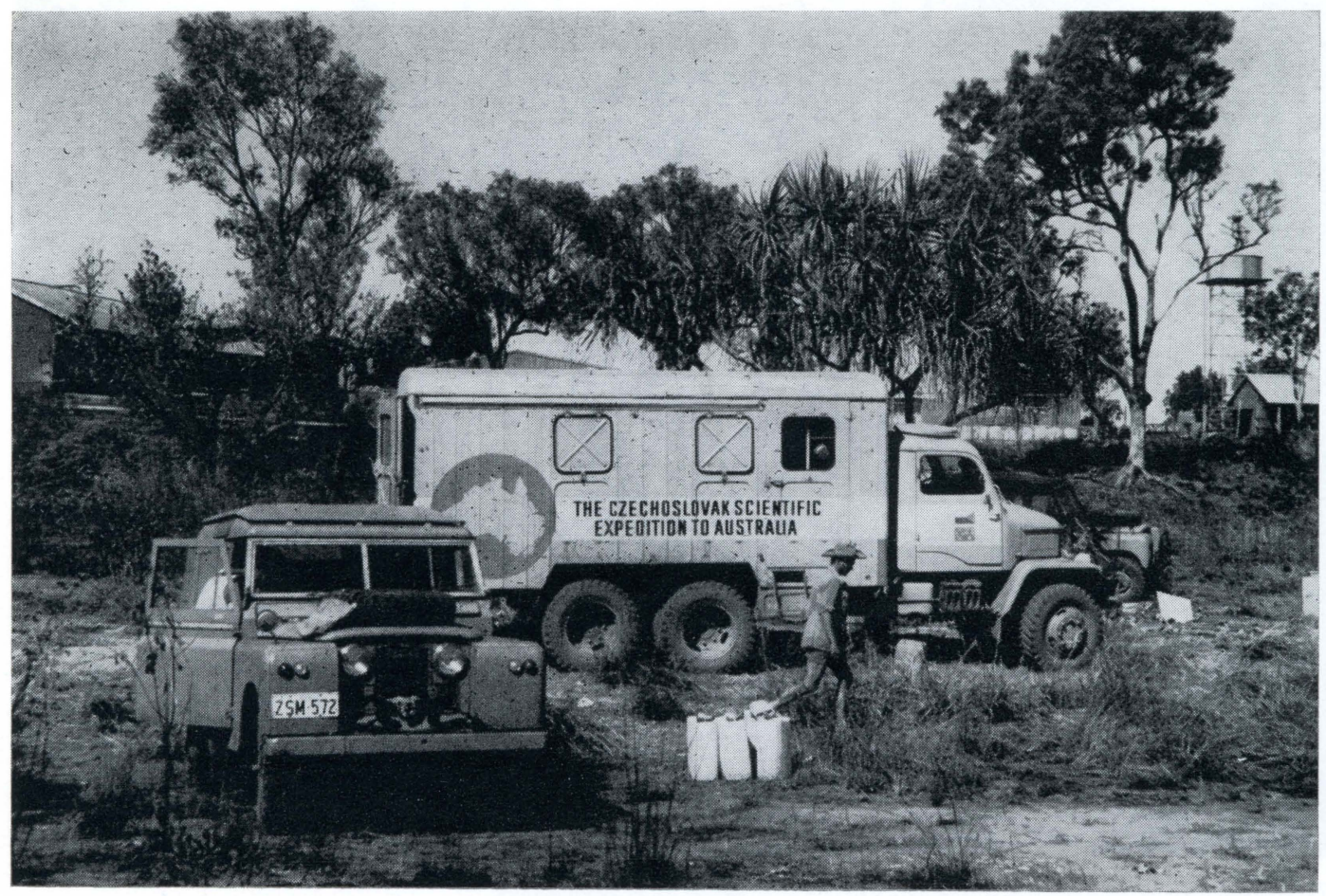

1. Base camp of Czechoslovak expedition in Bamyili.

2. Corroborree of Aboriginals in Beswick in Arnhem Land.

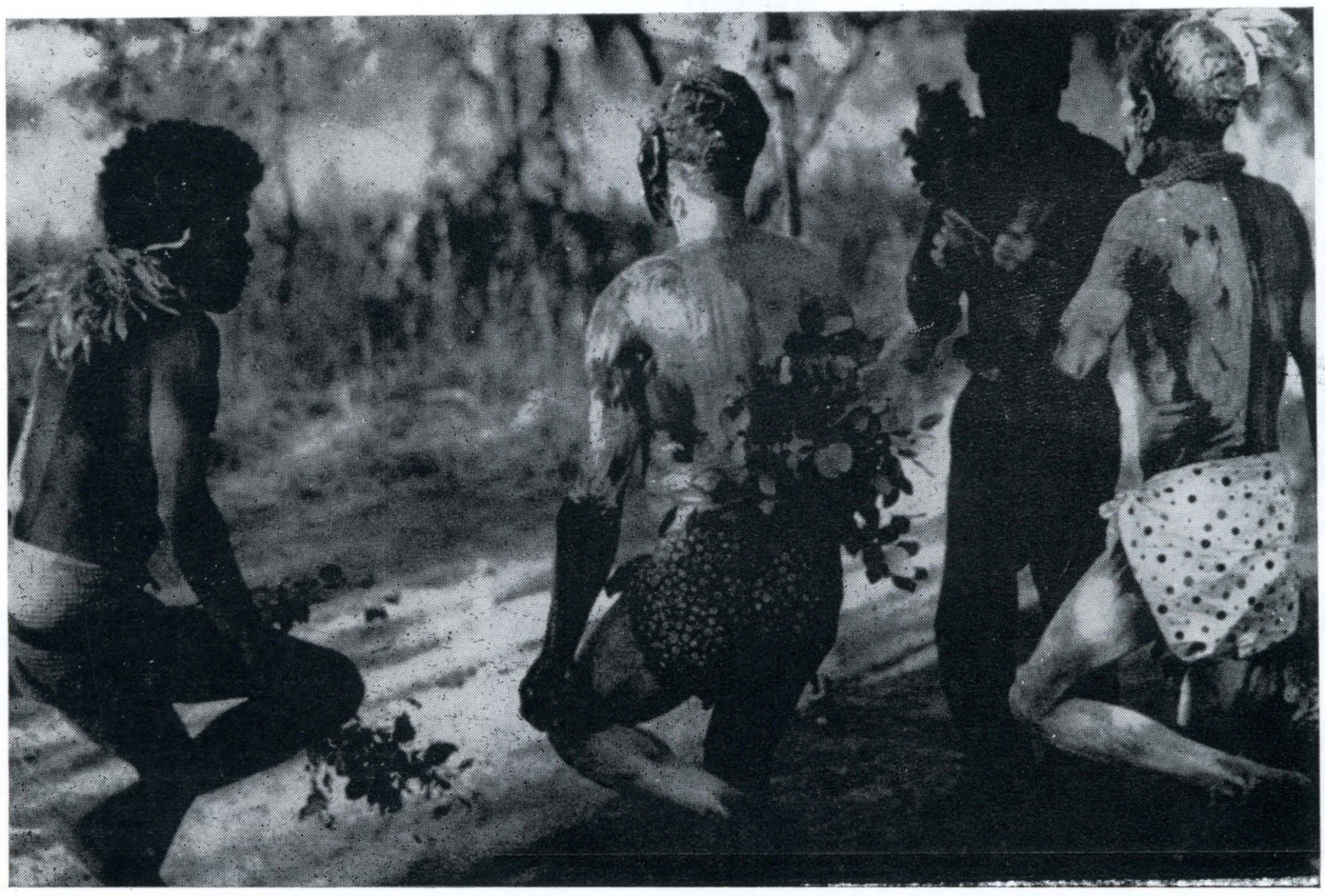



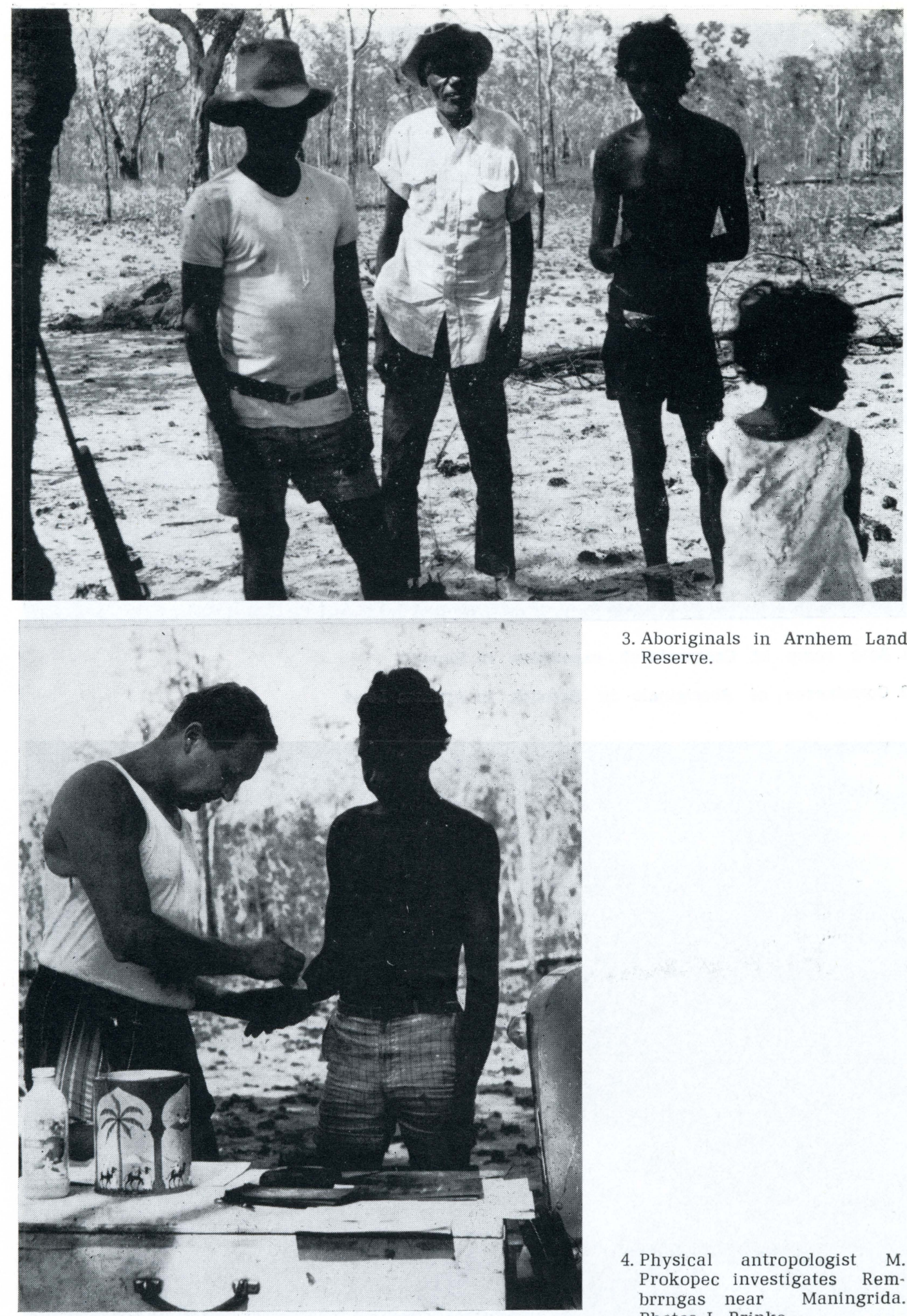

3. Aboriginals in Arnhem Land Reserve.

4. Physical antropologist $M$. Prokopec investigates Rembrrngas near Maningrida. Photos J. Brinke. 